https://doi.org/10.36910/6775-2410-6208-2021-6(16)-19

УДК 665.775+625.855.3

\title{
ВЛАСТИВОСТІ АСФАЛЬТОБЕТОНІВ, ВИГОТОВЛЕНИХ НА СПЕЦІАЛЬНИХ ДОРОЖНІХ БІТУМАХ
}

\section{PROPERTIES OF ASPHALT CONCRETE WITH SPECIAL PAVING GRADE BITUMEN}

Пиріг Я.І., к.т.н., с.н.с. (Харківський національний автомобільнодорожній університет, м. Харків), Ільїн Я.В., к.т.н., м.н.с. (Харківський національний автомобільно-дорожній університет, м. Харків), Роман П.С. (ДП «Дорожній науково-технічний центр», м. Київ)

Pyrig Y.I., Ph.D. in Engineering, S. Researcher (Kharkov National Automobile and Highway University, Kharkov), Iliyn Ia.V., Ph.D. in Engineering, Junior Reseacher (Kharkov National Automobile and Highway University, Kharkov), Roman P.S. (State enterprise «Road scientific and technical center», Kyiv)

У статті розглянуто вплив спеччіальних дорожніх бітумів (твердих та мультигрейд) на якість асфальтобетонів, виготовлених на ијих бітумах. Здійснено порівняння стандартних та реологічних показників якості асфальтобетонів, виготовлених на спеціальних бітумах та в'язких дорожніх бітумах, що використовуються в дорожній галузі України.

Residual deformations are one of the most spreaded defects in asphalt concrete pavements caused by an increase in traffic intensity and traffic load. Common ways of reducing the permanent deformations on asphalt concrete pavements is the use of pavements with high content of crushed stone and high-viscosity bituminous binders (bitumen modified with polymers or structuring additives). In the last 30 years, in different countries of the world, the design of high-modulus asphalt concrete pavements (EME, HiMA, HSMS) has become widespread, for which special road bitumen is used solid and multi-grade. The purpose of the work performed was to study the effect of special road bitumen on the properties of asphalt concrete and to assess the possibility of producing high-modulus asphalt concrete in accordance with national standards requirements. The paper compares the standard and rheological indicators of the quality of high-modulus asphalt concrete with special road bitumen (multi-grade Unibit 35/50 and solid bitumen 20/30 and 35/50) and hot asphalt concrete with the БНД 70/100 bitumen, which is widely used in Ukraine. The asphalt concrete studied in this work has a granulometric composition of stone materials that meet the requirements for the 
composition of high-modulus mixtures EME $0 / 20$ and the composition of asphalt concrete mixture of type A used in Ukraine with a maximum grain size of $25 \mathrm{~mm}$. Comparison of the properties of asphalt concrete with special bitumen and БНД 70/100 bitumen confirmed a significant improvement in the properties of asphalt concrete due to the use of special bitumen: the compressive strength at $20^{\circ} \mathrm{C}$ increases significantly (by a factor of $1.16-1.43$ times). Strength at $50^{\circ} \mathrm{C}$ increases by $1.42-1.86$ times. Coefficient of long-term water resistance increases to 0.99 - 1.0. Elasticity moduli at $40^{\circ} \mathrm{C}$ increase by 2.76 times, and at minus $10^{\circ} \mathrm{C}$ by 1.26 times. The temperature range of plasticity of asphalt concrete significantly expands (up to $100^{\circ} \mathrm{C}$ on bitumen 20/30). At the same time, for asphalt concrete made on high-viscosity bitumen, an increase in the conditional glass transition temperature is observed, which can lead to a decrease in the crack resistance of asphalt concrete. The use of multi-grade bitumen for the asphalt concrete results in an increase in the physical and mechanical parameters of the quality of asphalt concrete, a decrease in their temperature sensitivity, as well as a decrease in elastic moduli at low temperatures and an increase at high summer temperatures, which leads to an increase in shear resistance and a decrease in fracture resistance.

Ключові слова: спеціальні дорожні бітуми, твердий бітум, бітум мультигрейд, асфальтобетон, міџність на стиск, комплексний модуль пружності.

Keywords: special paving grade bitumen, hard bitumen, multigrade bitumen, asphalt concrete, compressive strength, stiffness,

Вступ. Постійне збільшення інтенсивності руху і транспортних навантажень $€$ однією 3 причин передчасного руйнування асфальтобетонних дорожніх покриттів, що в свою чергу призводить до скорочення як міжремонтних термінів, так і часу їх експлуатації. Найбільш поширеними дефектами асфальтобетонних покриттів $є$ пластичні деформації у вигляді колійності, хвиль, зрушень. Традиційними шляхами зниження пластичності є застосування асфальтобетонів із підвищеним вмістом щебеню, що дозволяє створити жорсткий кам яний скелет, або використання високо консистентних бітумних в яжучих (високов язкі бітуми; бітуми, модифіковані полімерами або структуруючими добавками). В Україні головними засобами підвищення міцнісних та пластичних характеристик дорожнього одягу є використання щебеневомастикових та асфальтополімербетонних сумішей. Вадою цього шляху $є$ те, що значного підвищення колієстійкості та зменшення пластичних деформацій можливо досягти лише за рахунок використання бітумів, модифікованих полімером, концентрація якого у в яжучому перевищує 7 - 
9\%, але використання таких високополімерних в яжучих в дорожній галузі України не $є$ поширеним через економічні та технологічні причини.

Аналіз публікацій. Останні 30 років у багатьох країнах світу набуває поширення влаштування асфальтобетонних покриттів із високими модулями жорсткості (EME - Enrobés à Module Elevé, HSMA - High Stiffness Modulus Asphalt або HiMA - High Modulus Asphalt), для виготовлення яких використовують зазвичай спеціальні дорожні бітуми (тверді бітуми 3 пенетрацією $5 \ldots .25 \times 0,1$ мм або бітуми мультигрейд 3 пенетрацією в межах $20 \ldots 70 \times 0,1$ мм) [1]. Перші досліди використання асфальтобетонних покриттів із високим модулем пружності були розпочаті у Франції у $80-x$ роках минулого століття [2, 3]. Саме тоді було запропоновано гранулометричні склади кам'яних матеріалів для цих асфальтобетонів, розроблено методику їх проектування, а також сформовано комплекс показників якості, що дозволяли оцінити їх особливості та переваги перед іншими асфальтобетонами [1]. Після отримання позитивного досвіду експлуатації високомодульних асфальтобетонних покриттів автомобільних доріг у Франції цей тип дорожнього покриття почали використовувати і в інших країнах світу. Найбільш досконалі дослідження щодо адаптування технології ЕMЕ до національних кліматичних, транспортних та методичних умов були виконані у Великобританії, Австралії та Південній Африці, крім цього, значні дослідження високомодульних асфальтобетонів здійснені в країнах Свропейського Союзу (Бельгії, Португалії, Данії, Швейцарії, Польщі), країнах Ближнього Сходу, Індії, Китаї [4 - 10].

Головними перевагами високомодульного асфальтобетонного покриття, порівняно з покриттям із класичного щільного асфальтобетону, $€$ [2]: збільшений модуль жорсткості, що досягається за рахунок використання твердих бітумів із пенетрацією, меншою ніж $25 \times 0,1$ мм; підвищений опір утомленості за рахунок більшої кількості в яжучого у складі асфальтобетону (близько $6 \%$, в той час як для звичайних асфальтобетонів із близьким зерновим складом кількість бітуму не перевищує 4,5\%) та низької пустотності, що є меншою на 6\%; підвищена колієстійкість покриття за рахунок використання високов`язких бітумів; покращена вологостійкість покриття за рахунок зменшення пористості асфальтобетону; підвищена зручноукладальність сумішей за рахунок підвищеної кількості бітумного в`яжучого, що спрощує ущільнення асфальтобетонної суміші; можливість зменшення товщини шару 
дорожнього одягу без зменшення міцнісних характеристик покриття, що сприяє зменшенню в свою чергу витрат на дорожнє будівництво. За рахунок притаманних цим асфальтобетонам властивостей вони знайшли поширення при влаштуванні дорожнього покриття на дорогах з високою інтенсивністю руху, в аеропортах, на зупинках важкого транспорту, в якості покриття мостових споруд тощо [1 -4].

Концепція виготовлення асфальтобетонних покриттів із високим модулем жорсткості передбачає не лише використання високов`язких (твердих) бітумів, а й виконання ще низки умов, до яких, зокрема, відносяться: розрахунок оптимальної кількості бітуму; заходи щодо проектування сумішей із більшою кількістю в`яжучих та меншою пористістю; непереривчаста гранулометрія; загальна кількість кам'яних матеріалів, дрібніших за 2 мм, повинна становити $32-35 \%$, кількість кам'яних матеріалів, дрібніших за 0,075 мм, повинна бути $7-8 \%$. Лише у цьому випадку ЕMЕ або НMA демонструють свої переваги перед покриттями, виготовленими з асфальтобетонних сумішей на звичайних в язких дорожніх бітумах.

На жаль, в Україні асфальтобетони з високим модулем пружності поки не використовуються, що може пояснюватись відсутністю необхідного бітумного в'яжучого (тверді бітуми в Україні не виготовляються i не імпортуються). Однак, зважаючи на постійно зростаючу інтенсивність дорожнього руху та підвищення навантажень від важкого транспорту, питання, пов'язані з дослідженням високомодульних асфальтобетонів в Україні, $є$ актуальними.

Мета і задача дослідження. Метою виконаної роботи було дослідження впливу спеціальних дорожніх бітумів на властивості асфальтобетонів та оцінка можливості виготовлення високомодульних асфальтобетонів, керуючись діючими національними стандартами. Для досягнення поставленої мети: адаптовано зернові склади кам'яних матеріалів високомодульних асфальтобетонних сумішей до зернових складів кам'яних матеріалів, що використовуються в Україні для приготування гарячих сумішей; здійснено порівняння стандартних та реологічних показників якості асфальтобетонів, виготовлених на спеціальних бітумах та в'язких дорожніх бітумах, що використовуються в дорожній галузі України.

Методи та об'скти дослідження. Для приготування асфальтобетонних сумішей використовувалися спеціальні тверді бітуми 
марки 20/30 i 35/50 та бітум мультигрейд марки Unibit 35/50, що виготовлені нафтопереробною компанією LOTOS Asfalt (Польща), а також широко розповсюджений в дорожній галузі України в'язкий бітум марки БНД 70/100, виготовлений ВАТ «Мозирський нафтопереробний завод» (Білорусь). Основні показники якості бітумів наведені в табл. 1.

Результати дослідження. Згідно наведених в табл. 1 даних 3 прийнятих бітумів найбільш виділяється бітум мультигрейд, що має найширший інтервал пластичності $\left(84,5^{\circ} \mathrm{C}\right)$ та найнижчу температурну чутливість (за індексом пенетрації він наближається до структурнореологічного типу «гель»), що повинно відповідним чином позначатися на властивостях асфальтобетону (уповільнювати динаміку зміни міцнісних показників зі зміною температури, особливо це є актуальним в діапазоні низьких експлуатаційних температур).

Тверді спеціальні бітуми (35/50 та 20/30) характеризуються високими значеннями когезії за температури $25^{\circ} \mathrm{C}$, що буде сприяти підвищенню міцності асфальтобетону. В той же час суттєвим недоліком цих бітумів $\epsilon$ підвищена температура крихкості (особливо для бітуму 20/30, яка становить мінус $6,5^{\circ} \mathrm{C}$ ), що може негативно позначатися на тріщиностійкості асфальтобетонних покриттів, виготовлених на цих в яжучих.

На основі аналізу зернових складів високомодульних асфальтобетонних сумішей ЕME, що були запропоновані у Франції, та гарячих асфальтобетонних сумішей, що використовуються в дорожній практиці України, встановлено, що зерновий склад асфальтобетонної суміші А з максимальною крупністю зерен кам`яного матеріалу 25 мм згідно ДСТУ Б В.2.7-119 [11] практично повністю відповідає вимогам французьких норм NF P 98-140 до складу сумішей ЕME 0/20. Виходячи 3 цього, для приготування асфальтобетонних сумішей було прийнято зерновий склад кам`яних матеріалів, що відповідав як вимогам ДСТУ Б В.2.7-119 (тип А) [11], так і NF P 98-140 (EME 0/20) (рис. 1).

При проектуванні складу асфальтобетонних сумішей важливою задачею є розрахунок оптимальної кількості бітуму. Згідно з прийнятою у Франції практикою вміст в'яжучого призначається за коефіцієнтом насиченості (К), значення якого є нормованим (для високомодульних сумішей $K>3,4)$ та визначаються за формулою 1 [6]: 


$$
K=\frac{\left(\frac{100 \cdot B}{100-B}\right)}{\alpha \cdot \sqrt[5]{\sum}},
$$

Таблиця 1

Властивості спеціальних дорожніх бітумів

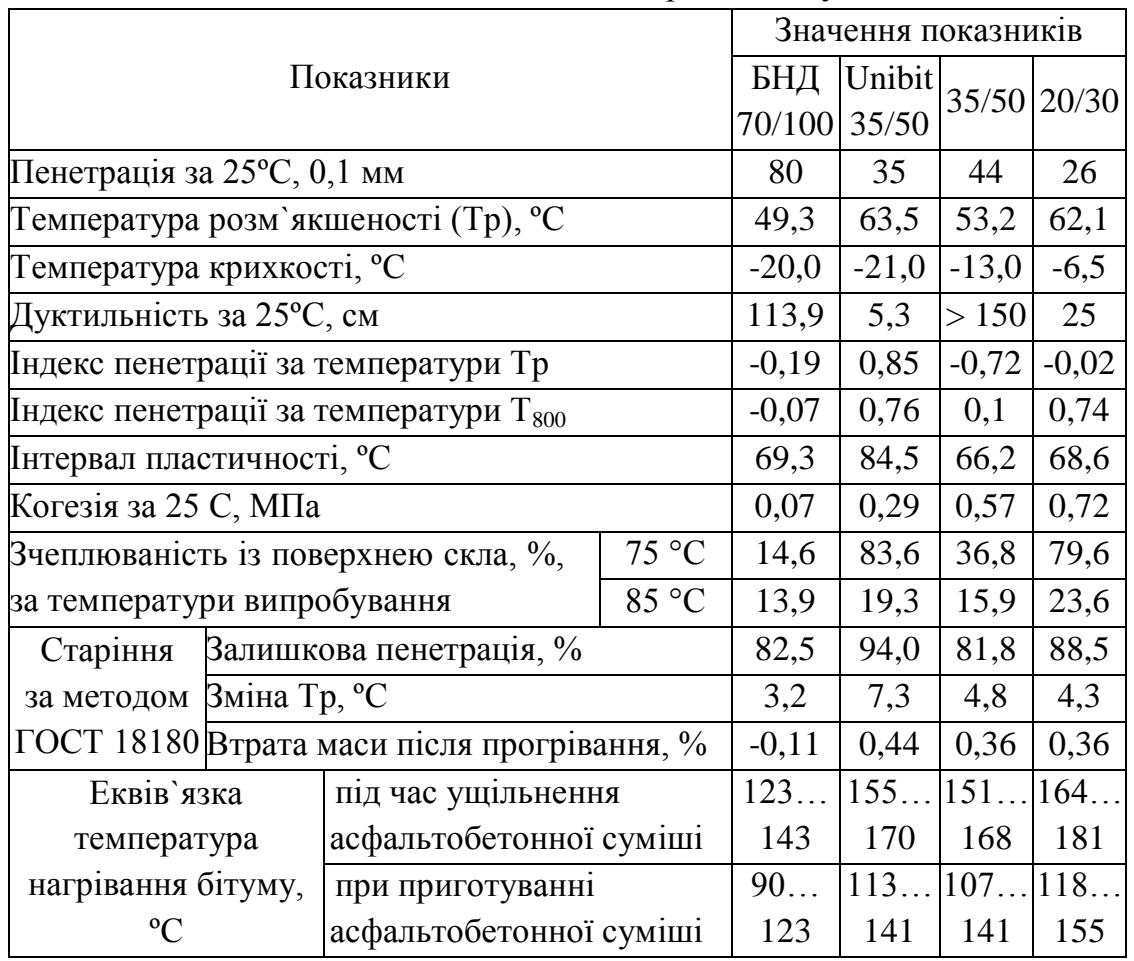

де В - вміст в'яжучого, \%, від загальної кількості асфальтобетонної суміші, $\alpha$ - поправочний коефіцієнт щодо щільності заповнювачів, що визначається за формулою:

$$
\alpha=\frac{2,65}{\rho_{a}},
$$

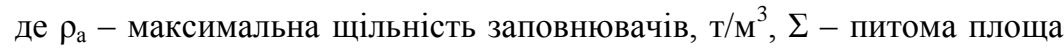
поверхні кам'яних матеріалів, м $^{2} / \kappa г$,

$$
\sum=(0,25 \cdot G+2,3 \cdot S+12 s+150 f) / 100
$$

де $\mathrm{G}$ - процент мінеральних зерен, більших 6,3 мм, $\mathrm{S}$ - процент 
мінеральних зерен від 6,3 мм до 0,25 мм, $\mathrm{s}$ - процент мінеральних зерен від 0,25 мм до 0,075 мм, f- процент мінеральних зерен дрібніше 0,075 мм.

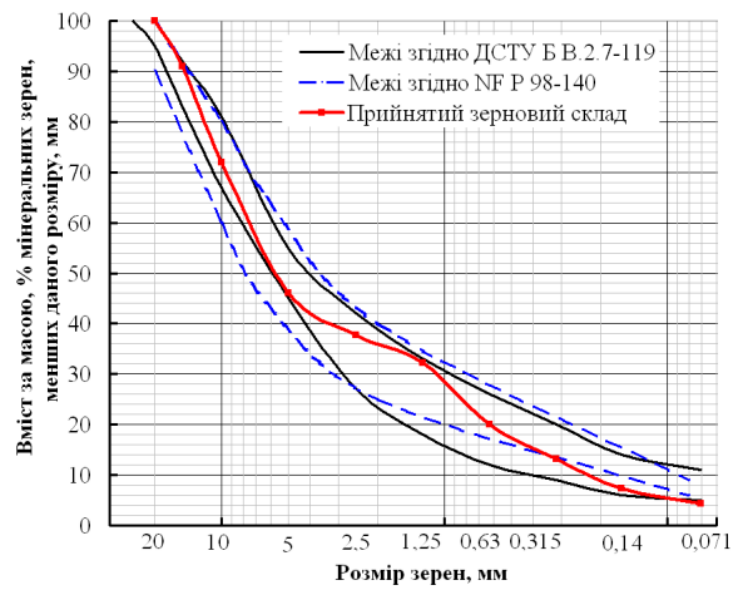

Рис. 1. Зернові склади асфальтобетонних сумішей

Для прийнятих кам`яних матеріалів та зернового складу асфальтобетонної суміші (рис. 1) розрахована оптимальна кількість бітуму становить 5,3 \%. Приготування та ущільнення асфальтобетонних сумішей здійснювалось згідно температурних режимів, встановлених за температурно-в 'язкісними залежностями бітумів (температури нагріву бітумів та температури ущільнення сумішей приймались відповідно максимальним температурам, наведеним в табл. 1, що в свою чергу відповідають однаковим значенням в'язкості бітумів).

Виготовлення асфальтобетонних зарізів в лабораторних умовах здійснювалось за допомогою секторного пресу WSV-KW30 з подальшим розрізанням на зразки-куби. Стандартні показники якості асфальтобетонів, виготовлених на прийнятих спеціальних бітумах, наведені в табл. 2.

Згідно отриманих даних, враховуючи, що гранулометричний склад мінеральної частини асфальтобетонних сумішей $є$ незмінним, головним фактором, що впливав на якість асфальтобетонних зразків, є властивості бітумів. При зменшенні пенетрації в'яжучого з $80 \times 0,1$ мм (асфальтобетон на бітумі БНД 70/100) до $44 \times 0,1$ мм (асфальтобетон на бітумі $35 / 50$ ) та $26 \times 0,1$ мм (асфальтобетон на бітумі 20/30), тобто в 1,82 та 3,08 рази, міцність на стиск асфальтобетонних зразків за температури $25^{\circ} \mathrm{C}$ зросла відповідно в 1,16 та 1,43 рази, а міцність на стиск за температури $50^{\circ} \mathrm{C}$ збільшилась відповідно у 1,86 рази та 1,42 рази. Зміна пенетрації 
в’яжучого майже не позначилась як на залишковій пористості асфальтобетонних зразків, яка для всіх асфальтобетонів знаходиться в межах 1,23-1,91\%, так i на середній густині - порівняно 3 асфальтобетоном на бітумі БНД 70/100 для асфальтобетону на бітумі 20/30

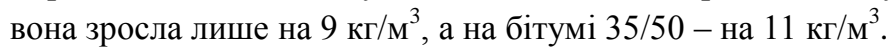

Таблиця 2

Властивості асфальтобетонних зразків, виготовлених на різних бітумах

\begin{tabular}{|c|c|c|c|c|c|}
\hline \multirow{2}{*}{ Показники якості } & \multicolumn{4}{|c|}{$\begin{array}{c}\text { Значення для } \\
\text { асфальтобетонів на бітумах }\end{array}$} & \multirow{2}{*}{$\begin{array}{l}\text { Норми } \\
\text { за [11] }\end{array}$} \\
\hline & $\begin{array}{c}\text { БНД } \\
70 / 100\end{array}$ & $\begin{array}{l}\text { Unibit } \\
35 / 50\end{array}$ & $35 / 50$ & $20 / 30$ & \\
\hline Середня густина, $\rho$, кг/м ${ }^{3}$ & 2438 & 2455 & 2449 & 2447 & - \\
\hline Водонасичення за об'ємом, W, \% & 0,39 & 0,21 & 0,08 & 0,45 & $\leq 4$ \\
\hline Залишкова пористість, \% & 1,91 & 1,23 & 1,47 & 1,34 & $2-5$ \\
\hline Міцність на стиск, МПа, за $20^{\circ} \mathrm{C}$ & 6,13 & 3,50 & 7,14 & 7,93 & $\geq 2,8$ \\
\hline $50^{\circ} \mathrm{C}$ & 1,44 & 2,10 & 2,68 & 2,05 & $\geq 1,3$ \\
\hline $\begin{array}{l}\text { Пористість мінерального кістяка, } \\
\text { \% об'ємом }\end{array}$ & 14,2 & 13,6 & 13,8 & 13,7 & $15-19$ \\
\hline $\begin{array}{l}\text { Коефіцієнт довготривалої } \\
\text { водостійкості }\end{array}$ & 0,93 & 0,99 & 1,00 & 0,97 & $\geq 0,88$ \\
\hline
\end{tabular}

Властивості асфальтобетону, виготовленого на бітумі мультигрейд, значно відрізняються від асфальтобетонів, виготовлених на високов'язких бітумах. Для цього асфальтобетону є характерним: найбільше збільшення середнього густини порівняно з асфальтобетоном на поширеній в Україні марки БНД 70/100 (на 17 кг/ $\mathrm{m}^{3}$ ); найбільше збільшення залишкової пористості (в 1,55 рази), а також зменшення міцності на стиск за температури $20^{\circ} \mathrm{C}$ та збільшення міцності на стиск на $50^{\circ} \mathrm{C}$ порівняно 3 бітумом БНД 70/100, що може пояснюватися суттєвою різницею в температурній чутливості в'яжучих.

Значного впливу високов'язкі бітуми надають на реологічні властивості асфальтобетонів, визначення яких виконувалось на вібростенді ХНАДУ, на якому реалізується схема випробування при динамічному деформуванні згідно вимог ДСТУ ЕN 12697-26:2018 [12]. Для випробування на вібростенді були прийняті такі параметри випробування: температура випробування - від мінус $10^{\circ} \mathrm{C}$ до $+40^{\circ} \mathrm{C}$, частоти деформування - від 0,01 Гц до 20 Гц. Температура випробування $15^{\circ} \mathrm{C}$ та частота деформування 10 Гц прийняті в якості контрольних для 
порівняння модулів пружності асфальтобетонів з вимогами, прийнятими для високомодульних асфальтобетонів в інших країнах світу [1 - 4]. Отримані дані наведені в табл. 3.

Таблиця 3

Реологічні показники асфальтобетонів, виготовлених на різних бітумах

\begin{tabular}{|c|c|c|c|c|c|c|}
\hline \multirow[t]{2}{*}{ Найменування показника } & \multirow{2}{*}{$\begin{array}{l}\mathrm{T}, \\
{ }^{\circ} \mathrm{C}\end{array}$} & \multirow{2}{*}{$\begin{array}{l}\mathrm{f}, \\
\Gamma ц\end{array}$} & \multicolumn{4}{|c|}{$\begin{array}{c}\text { Асфальтобетон типу А } \\
\text { на бітумі }\end{array}$} \\
\hline & & & $\begin{array}{c}\text { БНД } \\
70 / 100\end{array}$ & $35 / 50$ & $20 / 30$ & $\begin{array}{l}\text { Unibit } \\
35 / 50\end{array}$ \\
\hline \multirow{5}{*}{ 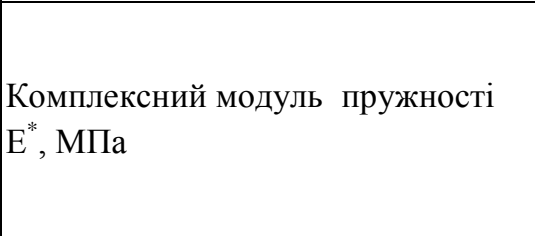 } & -10 & 0,5 & 19060 & 26920 & 19950 & 12020 \\
\hline & 0 & 0,5 & 14450 & 21880 & 16220 & 9550 \\
\hline & +15 & 0,5 & 5750 & 10720 & 11480 & 7940 \\
\hline & +15 & 10 & 8510 & 17378 & 15488 & 10233 \\
\hline & +40 & 0,5 & 1175 & 2950 & 3160 & 2460 \\
\hline $\begin{array}{l}\text { Умовна температура склування } \\
\mathrm{T}_{\mathrm{c \tau}},{ }^{\circ} \mathrm{C}\end{array}$ & - & 0,01 & 0 & 4,0 & 4,0 & $-11,0$ \\
\hline $\begin{array}{l}\text { Умовна температура переходу } \\
\text { до в’язкопластичного стану } \mathrm{T}_{\text {вп }},{ }^{\circ} \mathrm{C}\end{array}$ & - & 0,01 & 38 & 52 & 96 & 59 \\
\hline $\begin{array}{l}\text { Температурний інтервал } \\
\text { пластичності } \mathrm{T}_{\text {вп }}-\mathrm{T}_{\text {ст }}, \text { град }\end{array}$ & - & 0,01 & 38 & 56 & 100 & 70 \\
\hline $\begin{array}{l}\text { Показник температурної } \\
\text { чутливості } \Delta \operatorname{Lg~E} * / \Delta \mathrm{T}, 1 / \text { град }\end{array}$ & - & 0,5 & 0,025 & 0,019 & 0,016 & 0,014 \\
\hline
\end{tabular}

Згідно експериментальних даних (табл. 3) за різних температур модулі пружності асфальтобетонів одного гранулометричного складу, але виготовлених на різних бітумах, значно відрізняються. Найменша різниця у значеннях модулів пружності, визначених за частотою деформування 0,5 Гц, спостерігається в межах температур від $+10^{\circ} \mathrm{C}$ до $+20^{\circ} \mathrm{C}$, а особливо за температури $15^{\circ} \mathrm{C}$. Аналіз експериментально отриманих значень модулів пружності за температури $15^{\circ} \mathrm{C}$ та частоти 10 Гц свідчить про те, що асфальтобетони, виготовлені на твердих бітумах 20/30 та 35/50, відповідають нормативним вимогам до цього показника, прийнятими в різних країнах світу (у Франції та Австралії $\geq 14000$ МПа, у Південній Африці $\geq 16000$ МПа, у Великобританії $\geq 5500$ МПа) [1-3]. За цієї температури найбільший модуль пружності в асфальтобетону на бітумі 20/30, а найменший на бітумі БНД 70/100, що повністю корелює $\mathrm{x}$ мінцісними та в'язкісними характеристиками цих бітумів (табл. 1). Зі зміною температури тенденції зміни модулів пружності для 
асфальтобетонів, виготовлених на різних бітумах значно різняться. Найбільше відношення модулів пружності, визначених за температур мінус $10^{\circ} \mathrm{C}$ та $+40^{\circ} \mathrm{C}$ у асфальтобетону на бітумі БНД 70/100 (16,22 рази), а найменше - у асфальтобетону на мультигрейд (4,89 рази) (рис. 2). У асфальтобетонів на твердих бітумах 20/30 та 35/50 ці співвідношення становлять відповідно 9,13 та 6,31 разів. Це повністю корелює зі значеннями індексів пенетрації цих бітумів, визначених за температурою, що відповідає пенетрації $800 \times 0,1$ мм - відповідно мінус 0,07 у бітуму БНД 70/100, 0,1 у 35/50, 0,74 у 20/30 та 0,76 у Unibit $35 / 50$. Таким чином, чим менша температурна чутливість в'яжучого, тим повільніше змінюються значення модулів пружності асфальтобетонів зі зміною температури.

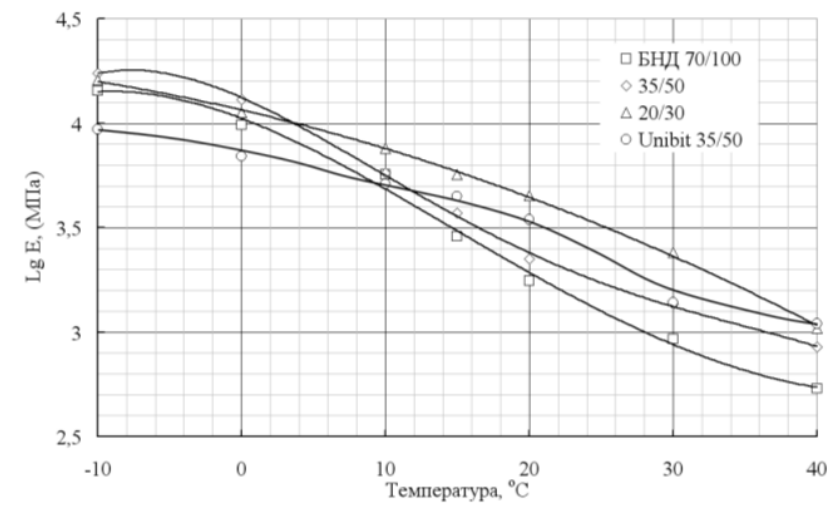

Рис. 2. Температурні залежності комплексного модуля пружності асфальтобетонів, виготовлених на різних бітумах за $\mathrm{f}=0,5$ Гц

Також зі значеннями індексів пенетрації бітумів добре корелюють значення показників температурної чутливості, розглянутих у роботі асфальтобетонів. Так, бітум мультигрейд відноситься до структурного типу «гель» та має найвище значення індексу пенетрації, а асфальтобетон, виготовлений на цьому бітумі, характеризується найнижчим значенням показника температурної чутливості. Бітуми БНД 70/100 та 35/50 за структурно-реологічним типом наближаються до типу «золь» (значення індексів пенетрації за Тр відповідно мінус 0,19 та мінус 0,72), а асфальтобетони, виготовлені на цих бітумах, мають найбільші значення показників температурної чутливості - відповідно 0,025 та 0,019. 
Таким чином, найкращу поведінку асфальтобетону в широкому інтервалі температур забезпечує використання бітуму мультигрейд. Саме асфальтобетону на цьому бітумі притаманні найвищі значення модулів пружності за температур вище $40^{\circ} \mathrm{C}$ (рис. 2), що забезпечить високу зсувостійкість та колієстійкість асфальтобетонного покриття за високих літніх температур, а також найнижчі значення модулів пружності за низьких зимових температур (нижче мінус $10^{\circ} \mathrm{C}$ ), що забезпечить високу тріщиностійкість асфальтобетонного покриття в зимовий період експлуатації автомобільної дороги.

Згідно з наведеними в табл. 3 даними зі зниженням пенетрації бітумів за $25^{\circ} \mathrm{C}$, у асфальтобетону спостерігається перехід до більш високих температур склування та значне збільшення умовних температур переходу до в'язкопластичного стану. Найвищі значення температури склування притаманні асфальтобетонам на твердих бітумах 20/30 та 35/50, що пояснюється відносно високими значеннями температури крихкості цих бітумів - мінус $6,5^{\circ} \mathrm{C}$ та мінус $13,0^{\circ} \mathrm{C}$, відповідно. Найнижче значення температури склування у асфальтобетону, виготовленого на бітумі мультигрейд (температура крихкості цього бітуму найнижча і становить мінус $21^{\circ} \mathrm{C}$ ), що буде сприяти підвищенню показника тріщиностійкості за низьких зимових температур цього асфальтобетону. Таким чином, при використанні твердих бітумів в якості в'яжучого для виробництва асфальтобетонних сумішей та влаштування асфальтобетонного покриття в кліматичних умовах України, треба застосовувати певні технологічні умови для зниження впливу низьких зимових температур на цей шар дорожнього покриття (наприклад, влаштування з такого асфальтобетону шарів основи дорожнього покриття чи влаштування з них нижнього шару дорожнього одягу тощо). Незважаючи на доволі високі значення умовної температури склування асфальтобетонів, виготовлених на твердих бітумах, вони характеризуються найширшими значеннями температурного інтервалу пластичності $\left(100^{\circ} \mathrm{C}\right.$ для асфальтобетону на бітумі $20 / 30$ та $56^{\circ} \mathrm{C}$ на бітумі 35/50), що дозволяє використовувати асфальтобетони, виготовлені на цих бітумах, для влаштування шарів дорожнього одягу в кліматичних районах зі значною різницею між високими літніми та низькими зимовими температурами.

Висновки. Порівняння властивостей асфальтобетонів зернового складу типу, що одночасно відповідав як типу А з максимальної крупністю зерен кам яного матеріалу 25 мм згідно ДСТУ Б В.2.7-119, так і EME 0/20, виготовлених на спеціальних бітумах (двох марок твердих та бітумі 
мультигрейд), а також на бітумі, що є найбільш поширеним у вітчизняній дорожній практиці (БНД 70/100), підтвердило значне покращення властивостей асфальтобетонів за рахунок використання спеціальних бітумів - міцність на стиск за $20^{\circ} \mathrm{C}$ зростає у 1,16 - 1,43 рази; міцність на стиск за $50^{\circ} \mathrm{C}$ зростає в $1,42-1,86$ рази; коефіцієнт довготривалої водостійкості зростає до 0,99 - 1,0; модулі пружності за температури $40^{\circ} \mathrm{C}$ зростають у 2,76 рази, а за температури мінус $10^{\circ} \mathrm{C}-$ у 1,26 рази; суттєво поширюється температурний інтервал пластичності асфальтобетонів (до $100^{\circ} \mathrm{C}$ на бітумі 20/30). В той ж час для асфальтобетонів, виготовлених на високов'язких бітумах, є характерним зростання умовної температури склування, що може призвести до зменшення тріщиностійкості асфальтобетонів, виготовлених на таких бітумах, за низьких зимових температур. Використання бітумів мультигрейд для приготування асфальтобетонів сприяє підвищенню фізико-механічних показників якості асфальтобетонів, зменшенню їх температурною чутливості, а також зменшенню модулів пружності за низьких температур та збільшенню за високих літніх, що призводить до збільшення зсувостійкості та зменшення тріщиностійкості.

\section{References}

1. Corté J.F. Development and uses of hard-grade asphalt and of high-modulus asphalt mixes in France. Transportation Research Circular. 2001. T. 503. P. 12-31.

2. Distin T., Vos R. EME - long lasting structural asphalt. Engineering Technology Forum - Queensland Transport \& Main Roads. September 2014. 10 p.

3. Le Bouteiller E. High Modulus Asphalt: The French Experience. Colas, AAPA Melbourne. 2012. 54 p.

4. Brosseaud Y., St-Jacques M. Les enrobés à module élevé : bilan de près de 30 ans d'expérience française (Partie 1 de 2). Revue Via Bitume, Vol. 10 № 2, pp. 8-15.

5. Nicholls J.C., Elliott R.C., Meite N.B., Perera R., Hunter A., Williams J. T. Monitoring the introduction of Enrobé à Module Élevé class 2 onto UK roads. Proceedings of the $4^{\text {th }}$ Eurasphalt and Eurobitume congress held May 2008, Copenhagen, Denmark, 2008. P. 519-529.

6. Petho L., Denneman E. EME technology transfer to Australia: an explorative study. Austroads, 2013. AP-T249-13. Sydney, A4, 60 p.

7. Denneman E. et al. High modulus asphalt (EME) technology transfer to South Africa and Australia: shared experiences. Proceedings of the $11^{\text {th }}$ Conference on Asphalt Pavements for Southern Africa (CAPSA). Sun City, South Africa. 2015. 7 p.

8. Sybilski D., Bańkowski W. Prace badawcze laboratoryjne iw pełnej skali nad zastosowaniem betonu asfaltowego o wysokim module sztywności w nawierzchni drogowej. Drogi i mosty. 2011. №. 1-2. p. 81-119.

9. Carbonneau X., Michaut J. P., Andersen T., Thorup C., Ladehoff L. High modulus GAB II: a Danish experiment. In Proceedings of the $4^{\text {th }}$ Eurasphalt and 
Eurobitume Congress Copenhagen, Denmark. 2008. p. 1-7.

10. Albayati A.H.K., Lateif R.H. Evaluating the performance of high modulus asphalt concrete mixture for base course in Iraq. Journal of engineering. 2017. T. 23. №. 6. C. 14-33.

11. DSTU B V.2.7-119:2011. Sumishi asfaltobetonni i asfaltobeton dorozhnij ta aerodromnyj. Texnichni umovy. [Chynnyj z 2011-30-12]. Vyd. oficz. Ky`yiv, Minregion Ukrayiny. 2012. $39 \mathrm{~s}$.

12. DSTU EN 12697-26:2018. Bitumomineralni sumishi. Metody vyprobuvannya garyachyx asfaltobetonnyx sumishej. Chastyna 26. Zhorstkist (EN 12697-26:2012, IDT). [Chynnyj z 2020-01-01]. K.: DP UkrNDNCz, 2018. 68 s.

\section{Список використаної літератури}

1. Corté J.F. Development and uses of hard-grade asphalt and of high-modulus asphalt mixes in France. Transportation Research Circular. 2001. T. 503. P. 12-31.

2. Distin T., Vos R. EME - long lasting structural asphalt. Engineering Technology Forum - Queensland Transport \& Main Roads. September 2014. 10 p.

3. Le Bouteiller E. High Modulus Asphalt: The French Experience. Colas, AAPA Melbourne. 2012. 54 p.

4. Brosseaud Y., St-Jacques M. Les enrobés à module élevé : bilan de près de 30 ans d'expérience française (Partie 1 de 2). Revue Via Bitume, Vol. 10 № 2, pp. 8-15.

5. Nicholls J.C., Elliott R.C., Meite N.B., Perera R., Hunter A., Williams J. T. Monitoring the introduction of Enrobé à Module Élevé class 2 onto UK roads. Proceedings of the $4^{\text {th }}$ Eurasphalt and Eurobitume congress held May 2008, Copenhagen, Denmark, 2008. P. 519-529.

6. Petho L., Denneman E. EME technology transfer to Australia: an explorative study. Austroads, 2013. AP-T249-13. Sydney, A4, 60 p.

7. Denneman E. et al. High modulus asphalt (EME) technology transfer to South Africa and Australia: shared experiences. Proceedings of the $11^{\text {th }}$ Conference on Asphalt Pavements for Southern Africa (CAPSA). Sun City, South Africa. 2015. 7 p.

8. Sybilski D., Bańkowski W. Prace badawcze laboratoryjne iw pełnej skali nad zastosowaniem betonu asfaltowego o wysokim module sztywności w nawierzchni drogowej. Drogi i mosty. 2011. №. 1-2. p. 81-119.

9. Carbonneau X., Michaut J. P., Andersen T., Thorup C., Ladehoff L. High modulus GAB II: a Danish experiment. In Proceedings of the $4^{\text {th }}$ Eurasphalt and Eurobitume Congress Copenhagen, Denmark. 2008. p. 1-7.

10. Albayati A.H.K., Lateif R.H. Evaluating the performance of high modulus asphalt concrete mixture for base course in Iraq. Journal of engineering. 2017. T. 23. №. 6. C. 14-33.

11. ДСТУ Б В.2.7-119:2011. Суміші асфальтобетонні i асфальтобетон дорожній та аеродромний. Технічні умови. [Чинний з 2011-30-12]. Вид. офіц. Київ, Мінрегіон України. 2012. 39 с.

12. ДСТУ EN 12697-26:2018. Бітумомінеральні суміші. Методи випробування гарячих асфальтобетонних сумішей. Частина 26. Жорсткість (EN 12697-26:2012, IDT). [Чинний з 2020-01-01]. К.: ДП УкрНДНЦ, 2018. 68 с. 